\title{
Introduction: Women, Professionalisation, and Patronage
}

\author{
Carme Font Paz and Nina Geerdink
}

The study of women's writing has become a lively field that has contributed and given rise to many new directions in the broader field of literary studies. Some of these, most importantly the 'material turn', have fuelled the theme of this volume: economic imperatives for women's writing. In the past three decades, with the greater availability of public records and archival materials, literary historians have tended to consider material aspects in their literary analyses and, as such, their collaboration with book historians has increased. Topics such as patronage and professionalism have burgeoned and moneymaking has been put on the agenda as an important factor within the literary field.

Material culture has contributed an invaluable framework for analysing a wealth of data regarding women's lives and works. The material turn was conceived in part as a scholarly interest in any aspect related to the business of writing that affected women's authorship and, thereby, scholars of women's literature have invoked it in many ways to enrich the scope of their inquiries. Nevertheless, the theme of moneymaking did not especially fit within this material subdomain. ${ }^{1}$ The socially inferior position of women and the rhetoric of modesty in their writing led to a predominant focus on social rather than economic imperatives for women's writing. This blind spot affects scholarship about women's writing across the European continent, although the focus on the production and consumption of women's literature in material terms has led to the identification and study of many English professional women writers from the eighteenth century. With regard to economic imperatives for women's writing, two important facts have often been disregarded or overlooked. These animate the purpose of this work: that women's socially inferior position was not a decisive limiting factor in their creative and professional

1 See for an overview of the connections between the study of women's writings and the material turn, Material Cultures of Early Modern Women's Writing, eds Patricia Pender and Rosalind Smith, Basingstoke 2014. See also Gillian Wright, Producing Women's Poetry. Text and Paratext, Manuscript and Print, Cambridge 2013. 
endeavours, and that economic professionalisation coexisted with patronage and was not, in many cases, incompatible with it.

For some decades now, scholars of culture have been aware that women in the book trade were neither scarce nor passive. Of the more than 300 English women identified as connected with the trade between 1557 and 1700, there may well have been some whose interest in the business was minimal and whose participation was therefore limited, but the everyday partnership of husband and wife in, for example, dividing responsibilities for shop keeping or in the supervision of apprentices is well-documented. ${ }^{2}$ Women could also own and run their own businesses, often after their husbands or fathers had died. Women are found to have been printing as well as bookselling and publishing, organising the distribution of newspapers as mercury women and hawking papers and pamphlets on the streets. This was an accepted practice in large parts of Europe. ${ }^{3}$

The background and activities of female authors in the sixteenth and seventeenth centuries appear to be less diversified. Women writers were most often from wealthy families. This is not only the case because of their education, but also because writing in this period was expensive in many ways. The opportunity to profit from writing grew, though, during the seventeenth and eighteenth centuries, even though as with their male peer writers, income from writing was rarely sustained. In this period, the number of women writers increased while their backgrounds varied more and more. According to Elaine Hobby, some 400 British women wrote between 1640 and 1700, and over one-half of these writers produced tracts of a religious and political nature. ${ }^{4}$ Stanton adds to this data saying that "the numbers of women starting to write, decade by decade,

2 The Cambridge History of the Book in Britain, 1557-1695, Cambridge 2008, vol. IV, 440-41.

3 See about women in the early modern book trade in Europe G. Sheridan, "Women in the Book Trade in the 18th Century: An Untold Story", in Writing the History of Women's Writing. Toward an International Approach eds Suzan van Dijk et al, Amsterdam 2001, 197-210; specifically, for England: The Cambridge History of the Book, Maureen Bell, "Women in the English Book Trade 1557-170o", Leipziger Jahrbuch zur Buchgeschichte, 6 (1996), 13-46 and Tamara Hunt, "Women's Participation in the Eighteenth-Century English Publishing Trades", LeipzigerJahrbuch zur Buchgeschichte 6 (1996), 47-66; for Germany: Mark Lehmstedt, "'Ich bin nun vollends zur Kaufmannsfrau verdorben'. Zur Rolle der Frau in der Geschichte des Buchwesens am Beispiel von Friederike Helene Unger (1751-1813)", Leipziger Jahrbuch zur Buchgeschichte 6 (1996), 81-154; for France: G. Sheridan, "Women in the booktrade in eighteenth-century France", British Journal for Eighteenth-Century Studies 15 (1992), 52-69; for Italy: D. Parker, "Women in the Book Trade in Italy, 1475-162o", Renaissance Quarterly 49/3 (1996), 509-41; and for the Dutch Republic: Paul Hoftijzer, "Women in the Early Modern Dutch Book Trade", in Writing the History of Women's Writing eds Suzan van Dijk et al, 211-22.

4 Elaine Hobby, Virtue of Necessity: English Women's Writing 1649-88, London 1988, 27. 
increased steadily but slowly from the 1660 os to the 1730 s. $^{5}$ For other European countries, a relatively comparable increase has been noted, particularly in France, but also in Spain, Italy and the Dutch Republic. ${ }^{6}$ The early decades of the eighteenth century are marked in some countries by "a new cultural power for women" as part of the consolidation of middle-class hegemony, ${ }^{7}$ in which many women made their living by their pen, which meant that they earned money from the books they published, but most often from their freelance work (or hackwriting) in the buoyant press or the theatre. In some cases, such as in Britain, women's presence in the writing market was so normalised that they became invisible as authors, a "nobody story" of individuals whose authorship had transformed into a commodity and, therefore, a "vanishing act". ${ }^{8}$ As we shall see, professionalisation of writing, and the recognition of women as authors with an audience, was not incompatible with the practice of patronage in many instances. E.J. Clery defines this scenario for the second half of the eighteenth century as a slight and gradual "modification of the patronage system, involving an admission of need and dependency, and with an even greater degree of selfadvertisement and public exposure". ${ }^{9}$ In both models, the success of their work depended on readers' satisfaction, social impact or sales. However, often the professional model implied that the audience was broader and more diversified.

With the historical intersection of increasing possibilities to profit for a larger number of women writers as a starting point, this volume adds a chapter to the history of profitable writing in the early modern period.

\section{Economic Imperatives in the Literary Field}

The history of the professionalisation of the literary field in Europe needs further scholarly attention and requires a comparatist approach. The large

5 Judith P. Stanton, "Statistical Profile of Women Writing in English from 1660 to 180o", in EighteenthCentury Women and the Arts eds Frederick Keener and Susan Lorsch, New York 1988, 251.

6 Cf. for the Dutch Republic, Women's Writing from the Low Countries 1200-1875/A Bilingual Anthology, eds Lia van Gemert et al, Amsterdam 2010, 64. Cf. for the Spanish case, The Routledge Research Companion to Early Modern Spanish Women Writers, eds Nieves Baranda and Anne J. Cruz, New York 2017, 1-12. Cf. for the French case, A History of Women's Writing in France, ed. Sonya Stephens, Cambridge 20oo. Cf. for the Italian case, Letizia Panizza, A History of Women's Writing in Italy, Cambridge 2001.

7 Cf. Nancy Armstrong, Desire and Domestic Fiction. A Political History of the Novel, Oxford 1987; Jane Spencer, The Rise of the Woman Novelist, Oxford 1986.

8 Cf. Catherine Gallagher, Nobody's Story: The Vanishing Acts of Women Writers in the Marketplace $1670-1820,1994$.

9 E.J. Clery et al, Authorship, Commerce and the Public: Scenes of Writing, 1750-1850, London 2002. 
number of studies into professionalisation in early modern England and comparatively fewer studies about other national traditions show differences in dates and details but share a remarkable teleological line that can no longer be taken for granted. The narrative of the professionalisation of the literary field that prevailed for so long suggested that money at first did not play a role in literary authorship and only really became a dominant factor in the nineteenth century. ${ }^{10}$ The emergence of literature written for a general public was, in this view, connected to the rise of the market. Debates surrounding the topic claimed that, in the sixteenth and seventeenth centuries, authors were dependent on patronage and on a balance between writer-patron that was not always meant to make the author's living, but to procure social or political advantage: writers often occupied a position to earn their daily bread or they were from rich descent. For most countries, the traditional narrative suggested that the patronage system during the eighteenth century was replaced by a commercial system in which authors saw more and more possibilities to make a living out of writing - although they often still needed to do side-jobs, such as editing, translating and lecturing. Moreover, writing as a profession still remained unacceptable among the literary elite for most of the century. In this view, literary writing only became a real 'profession' in the nineteenth century, with authors able to work independently from patrons, church and state. Authors were now in a paradoxical situation in which they used the market to make money with their writings even though many struggled with commercial success or lack of it, while simultaneously and continuously demonstrating their independence from this market.

The traditional narrative is an idealisation in itself, as really living from literary writing is still a difficult feat for the happy few. Moreover, the tension between literature and the market still exists today and existed prior to the nineteenth century. In present times, literary writers often have difficulties making a living - unless they are a bestselling author, like E.L. James and Dan Brown and, as a bestselling author, writers are frequently forced to defend themselves against accusations of commerciality. Bestselling authors are still often criticised as not being 'real' literary authors and of producing pulp instead of real

10 This narrative is referred to by, among others, Dustin Griffin, Authorship in the long Eighteenth Century, Newark 2014, esp. 171-185; M. Rose, "The Author as Proprietor", Representations 23 (1988), 51-85; M. Woodmansee, "The Genius and the Copyright: Economic and Legal Conditions of the Emergence of the Author", Eighteenth Century Studies 17/4 (1984), 425-28; Alain Viala, Naissance de l'écrivain. Sociologie de la littérature à l'âge classique, Paris 1985; Gerard Bouwmeester, Nina Geerdink and Laurens Ham, "Een veelstemmig verhaal. Auteurschap in de Geschiedenis van de Nederlandse literatuur", Nederlandse letterkunde 20/3 (2015), 215-36. 
Literature. Therefore, no aspect of this complex relationship between money and literature is really new. Indeed, even during the Renaissance, writers were occupied with framing their work and that of others in relation to money, for example, by assuring readers of their independence and sincere reasons for writing, by complaining about a lack of possibilities of patronage, or by criticizing hack writers. This shows in fact that money played an important role in the literary field, long before 1800 .

During the last three decades, scholars have begun to discuss the history of the professionalisation of the literary field in a critical manner, and to ask whether the teleological narrative does justice to the dynamics of developments related to money. Patronage has much in common with the literary market, both in its systematics and in its relationship to money: patronage was often more related to an author's daily bread than has been assumed by seventeenth-century authors themselves and by scholars analysing their work some decades ago. ${ }^{11}$ Moreover, as early as the sixteenth century, there were poets relying less on patronage and on circulating their writings (as opposed to printing them). They must be regarded as professional authors or at least as authors who discussed the possibilities granted by commercial authorship. ${ }^{12}$ Geoffrey Turnovsky's contention that the transition from patronage to market was not a fundamental break, but a natural process in which more exteriorities than intellectual values were replaced also fits in, as does Dustin Griffin's argument about the coexistence of a system of patronage and of commerce during the long eighteenth century. ${ }^{13}$ Voices like these reemphasise the significance of research and debate on the dynamics and importance of moneymaking for pre-18oo literary authors.

The period between 1650 and 1800 is still commonly acknowledged as one in which the commercial literary marketplace and a culture of professional authorship emerged. Indeed, larger numbers of writers (poets, playwrights, satirists and novelists) participated in a growing field of commercial exchange in which the main commodity was intellectual and creative capital. Several

11 Helen Smith, Grossly Material Things. Women and Book Production in Early Modern England, Oxford 2012; Andrew Pettegree, The Book in the Renaissance, New Haven 2010, 16166; Nina Geerdink, Dichters en verdiensten. De sociale verankering van het dichterschap van Jan Vos (1610-1667), Hilversum 2012.

12 Laurie Ellinghausen, Labor and Writing in Early Modern England, 1567-1667, Aldershot/ Burlington 2008; Joseph Loewenstein, "Wither and Professional Work", in Print, Manuscript and Performance eds A.F. Marotti and M.D. Bristol, Columbus $\mathrm{OH}$ 200o; Sarah Prescott, Women, Authorship and Literary Culture, 1690-1740, Houndmills/New York 2003.

13 Geoffrey Turnovsky, The Literary Market. Authorship and Modernity in Old Regime France, Philadelphia 2010; Griffin, Authorship. 
scholars have sought to define the exercise of authorship in this transitional phase between medieval and Renaissance concepts of autoritas as agency and authorship in Romantic terms. Mark Rose and Alvin Kernan, for instance, discussed the modernity of early eighteenth-century literary culture (as opposed to the celebrated birth of the modern talented author in the advent of Romanticism).${ }^{14}$ According to Kernan, the new literary marketplace freed "the writer from the need for patronage and the consequent subservience to wealth [...] through a copyright law that made the writer owner of his own writing." ${ }^{15}$ This was a major shift, but one which, for Dustin Griffin and Margaret Ezell, was not a determining factor to significantly change authorial practices and contexts of production. ${ }^{16}$ As we have seen, and as this book contends, manuscript culture, patronage systems and leisure writing coexisted and coalesced in a growing commercial market that was transforming literary output - not only journalistic or informative writing - into a commodity that was more subject to rules of supply and demand.

To use a Foucauldian term, the concept of what or who was an author was also modified along with its sphere of influence. We cannot refer to the professionalisation of authorship at a time in which the notion of 'genius' or individual talent was hardly taken into account as a distinctive trait. Writing as an artistic expression was a social act, often linked to the taste and political expectation of its intended audience (patrons, sectarian groups, or reduced audiences which read in a culture of manuscript circulation) rather than to notions of originality and aesthetic quality. The emergence of a commercial market did not change the imperatives of having to 'satisfy' a growing and diverse audience in order to succeed as a writer. At the same time, more possibilities to achieve public exposure in more impersonal terms existed.

\section{Economic Imperatives for Women's Writing}

This volume seeks to contribute discussions about patronage, professionalism, authorial reputations and economic imperatives from the perspective of early modern women's writing in Europe. It will do so by opening up the research into economic imperatives for women's writing in two ways: by adding a

\footnotetext{
14 Alvin Kernan, Samuel Johnson and the Impact of Print, Princeton 1989; Mark Rose, Authors and Owners: The Invention of Copyright, Cambridge 1993.

15 Kernan, Samuel Johnson, 5.

16 Margaret Ezell, Social Authorship and the Advent of Print, Baltimore 1999; Griffin, Authorship.
} 
comparative European perspective, and - taking the discussions about professionalism and patronage as a starting point - by enlarging the group of women writers for whom the perspective of economic imperatives is relevant.

In literary histories of most single European countries, the field of economic imperatives for women's writing in the seventeenth and eighteenth centuries has been neglected. Whereas money, as a consequence of the dominance of the traditional narrative in the historiographies of many literatures, is said to play a minor role in the literary production before 1700, and a role that was growing, but not dominant until 180o, the importance of money for female authorship seems to have been underestimated even more. The only country whose women writers have been thoroughly studied from the perspective of moneymaking is England. A case in point is the work of the sixteenth-century author Isabella Whitney (1567-1573), who represented herself as a maidservant writing in need of money. Her work has been tackled as an exception and scholars have tried to explain her extraordinary self-representation in terms of networking. In 2005, Laurie Ellinghausen was the first to interpret it as part of a professional authorship. ${ }^{17}$ Cases such as Whitney's are scarce in the sixteenth century, but from the late seventeenth century onwards the number of professional women writers rises and so does the amount of studies into their authorship. ${ }^{18}$

The insights stemming from research into English women writers and their relationship with money have not yet radically changed literary historical perspectives on women's writing in other European countries, nor stimulated comparative research into female professional authorship. ${ }^{19}$ In some European countries, research into women's writing is still in its exploratory phase. In many literary histories of the early modern period, women writers remain the exceptions. In countries where this has changed over the last decades, research into now well-known women writers needs to be elaborated on, particularly with regard to where economic imperatives presumably play a role. This is

17 Laurie Ellinghausen, "Literary Property and the Single Woman in Isabella Whitney's $A$ Sweet Nosgay", Studies in English Literature 1500-1900 45 (2005), 1-22; Ellinghausen, Labor and Writing.

18 Cheryl Turner, Living by the Pen. Women Writers in the Eighteenth Century, New York/London 1992; Paula McDowell, The Women of Grub Street: Press, Politics, and Gender in the London Literary Marketplace, 1678-1730, Oxford 1998; Betty Schellenberg, The Professionalization of Women Writers in Eighteenth-Century Britain, Cambridge 2005.

19 This is due to a general lack of in-depth comparative studies regarding women's literature, as is signalled by Martine van Elk in Early Modern Women's Writing. Domesticity, Privacy, and the Public Sphere in England and the Dutch Republic, Cham 2017, which itself is an example of such a study. 
not easy, since women's position within literary histories blurs their routes to professional authorship and other forms of engagement with financial gain. This means that the idea of economic imperatives for women's writing is often covered by the way in which women writers have entered literary histories.

Female authorship has been treated as a different 'category' from canonical or even male authorship. The focus on the literary history of female authorship has been on restrictions rather than on possibilities. ${ }^{20}$ Women writers, who traversed the boundaries of the private sphere they were bound to, were exceptions, and the active and growing participation of women writers in the literary field was something new during the early modern period. Therefore, the conditions and difficulties of women's entrance in the literary field have been highlighted in scholarly analysis, supposing that being accepted there as a woman was something to be grateful for instead of a position that, once earned, could be used for earning.

At least two defining characteristics of early modern women's writers and their texts have contributed to a blurred view of their economic imperatives. Firstly, female authors were often women from the elite. In any case, up to the eighteenth century, a literary author required some formal or informal education. These women thus often came from wealthy families and did not need to earn anything from their writings. What is often omitted, however, is that women writers from lower classes also wrote, such as the British Mary Leapor $(1722-1746)$, as we shall see in this volume. In the English case, a 'shifted critical lens' revealed that many female authors were from the lower classes. ${ }^{21}$ Moreover, women descending from wealthy families sometimes became poverty stricken, as many case studies in this volume will show.

Secondly, the study of women's writing is often confined to their private circles in keeping with the early modern moral that excluded public functions for women. Kim Walker cleverly summarises this with her contention: 'If writing for a public audience could be interpreted as unchaste, then writing for financial gain could be read as a form of prostitution.'22 Women often justified their writings by representing them as a dutiful fulfilment of their free time, as opposed to labour for financial gain, and therefore deflecting attention by fulfilling societal, male expectations in their self-representation. ${ }^{23}$

\footnotetext{
20 Schellenberg, The Professionalization.

21 McDowell, The Women, 14.

22 Quoted in Ellinghausen, Labor and Writing, 20.

23 Jennie Batchelor, Women's Work: Labour, Gender, Authorship 1750-1830, Manchester/ New York 2012. About women in between private and public spheres see also Van Elk, Early Modern Women's Writing.
} 
Aspects of women's (self-)representation have caused the more extensive Anglo-American scholarship into women's writing to tend to privilege those writers who appeared more openly concerned with profit or their public image as 'respectable females'. Relying on the work of Margaret Ezell, Sarah Prescott makes a distinction between successful professional authors, presenting themselves as such, and the so-called 'genteel amateurs', writing for their own circles and presenting themselves very modestly. ${ }^{24}$ The first category, that of professional authors, was active in public and not as easily overlooked by literary historians as the women writing for their private circle or, at least, presenting themselves as doing so. Models of female authorship that had arisen out of the emphasis on the professional woman writer could be based on a sexualised trope: either the anti-feminist image of the woman writer as a libertine, or as a modest amateur. Kathryn King has called this a "moralized taxonomy" which has haunted women's literary history of this period in particular. ${ }^{25}$ Such labels have also obscured other factors that shaped women's writing, such as political affiliation and religious belief, especially before the $1720{ }^{26}$

Women writers who did not present themselves as professionals, but who did relate to financial gain one way or the other - for example, by being part of relationships of patronage - were certainly numerous and should not be overlooked. There was some money to be made in writing, and many women were attracted to it by economic necessity, whereas others did not have to make a living out of their writing, even though they could receive some occasional payment. Cheryl Turner calls the latter group "dependant professionals", and while they were more prone to hack for bread, it is not at all the case that women who made money out of writing did it out of commissioned work only. ${ }^{27}$

At the same time, some of these women might have been free from economic imperatives, but still could be regarded a professional author. Anna Seward, for example, the "Swan of Lichfield" (1742-1809), enjoyed a successful career as an early and published Romantic poet writing from the countryside and making no mention whatsoever in her correspondence of any financial gain. She was, however, very much concerned about her reputation as a writer beyond her condition as a woman. Together with other women who were neither cosmopolitan nor particularly (or publicly) concerned with financial gain, such as

\footnotetext{
24 Margaret Ezell, Social Authorship and the Advent of Print, Baltimore 1999; Prescott, Women.

25 Kathryn King, "Elizabeth Singer Rowe's Tactical Use of Print and Manuscript", in Women's Writing and the Circulation of Ideas: Manuscript Publication in England, 1550-1800, ed G.L. Justice and N. Tinker, Cambridge 2002, 75 .

26 Hobby, Virtue of Necessity.

27 Turner, Living by the Pen, 6 .
} 
Lady Mary Chudleigh or Elizabeth Singer Rowe in the British scene, the notion of being both an author and a professional one at that might have more to do with women's ability to be published and read on a consistent basis, regardless of whether the token of exchange for this access was economic or otherwise. Some of these women resorted to self-publishing and succeeded as writers with considerable broad audiences.

In other words, did financial gain authorise or diminish the literary standing of authors, whether male or female? Was a self-published author less professional than an author released by a commercial publisher? This is still an unresolved issue that, to our mind, is best approached by considering how women negotiated the economic aspects which they encountered in their particular case, whether these were copyright issues and direct profit, consequences from the gift-sphere of patronage, or a combination of both, how they alternated artistic creation with hacking as translators or journalists, how they managed and effected payment of copyrights or patronage services, or how they managed subscription as an alternative way of generating income and leverage as authors. This book is chiefly concerned with how economic factors impinged on women's literary output and how the realisation that their writing was subject to commercial exchange affected their self-representation as authors.

This representation involved not only the authors themselves, but also many other social agents. The literary marketplace relied on older traditional writing practices to conceptualise the author who went to print. For instance, the periodicals and miscellany writings, two of the most popular, original and eclectic types of publication, were based on manuscript circulation and modes of social authorship associated with coteries. ${ }^{28}$ This would suggest, once again, that manuscript and print cultures were not separate modes of authorship at that time, but that both configured, reflected and regulated the economy of exchange that played out in the literary marketplace. Ultimately, what remains to be ascertained are the ways in which the new reconfiguration of authorship informed the market and its audience, and how these in turn modified the concept of authorship. The figure of the publisher mediated, filtered and decided upon the flow of works that entered public opinion, and this regulation was based on criteria of profitability and impact. Women, as well as men, were made to negotiate their entrance to this flow by marketing and fashioning themselves to their intended audiences. Authors were attached to their publishers, audiences and patrons; agents dually or triangularly related to each other.

28 Margaret J.M. Ezell, “The Gentlemen's Journal and the Commercialization of Restoration Coterie Literary Practices", Modern Philology 89/3 (1992), 323-40. 


\section{The Chapters in This Volume}

The case studies collected in this volume relate to authors working at various moments in the seventeenth and eighteenth centuries, and in different Western European countries. This accounts for changing (pre)conditions for the development of women's writing and women's literary careers. Still, it is possible to derive two general conclusions. What all chapters show is, firstly, that the women writer's financial gain during the whole period and in every country, in some way or the other, was framed as exceptional; and, secondly, that a sharp distinction between patronage and professionalism in connection to financial gain and (self)representation is impossible.

Suzan van Dijk in our opening chapter does not elaborate on one case but shows how the framing of financial gain as exceptional for early modern women writers continued until far into the nineteenth century by analysing biographical works of the eighteenth and nineteenth centuries. It turns out women writer's financial gain needed to be defended by referring either to the woman's role as a benefactor, supporting others with the money earned, or to her poor position, being an appropriate object of charity.

Each of the following chapters present cases of women writers who relate to financial gain. As such being framed as exceptional leads them either to proudly present themselves as professionals, or to veil their economic imperatives and present themselves modestly as amateurs. Examples of the first are the relatively well-known cases of Charlotte Lennox and Sophie Albrecht, both active in the eighteenth century, in England and Germany respectively. From the chapters by Marianna D'Ezio and Berit Royer, it appears that - as a translator (Lennox) and a novelist-publisher (Albrecht) - they profited from the popularity of the genre of the novel in their time, along with the encompassing professionalisation of women's writing that this entailed. This was not the case for the early example of the Danish-Norwegian Dorothé Engelbretsdatter, who was in her own time as proudly successful as any eighteenth-century novelist. In her chapter, Marie Nedregotten Sørbø describes how she was nevertheless overlooked in literary history for a substantial period, therewith showing how being a professional woman writer outside of eighteenth-century England means staying out of the picture of many literary historians. These three women writers obtained benefit not only from their professionalism, but also from being termed as professional writers. In many instances, there was no benefit in such a representation.

Cases of women representing themselves modestly, or not proudly engaging in the commercial book market, form the greater part of this volume. Sometimes, the attempt to earn through literary activity really was a measure of 
emergency, such as in Nina Geerdink's case of the Dutch Elisabeth Hoofman, who early in the eighteenth century refused to publish her works up until the moment she lost her income and she needed to improve her relationship of patronage by publishing some laudatory poems. It is also evident, in Carme Font Paz's case of the English Aemilia Lanyer, who tried to obtain patronage in court circles of the late sixteenth century after her businesses failed. A case in point is the scarcely known British Ann Yerbury writing poetry in the early decades of the eighteenth century, described in the same chapter, who obtained enough of an income separate from her writings and, therefore, did not publish them, nor maintained relationships of patronage on the basis of manuscripts. Moreover, in her chapter on the eighteenth-century Eleonora de Fonseca Pimentel from Naples, Irene Zanini-Cordi analyses how intellectual and ideological imperatives - in the end more important than economic ones - were often overruled by the need to make money.

Eighteenth-century Venice, as the centre of Italian publishing and culture with a long tradition of Renaissance art, is an European locus that shows the shift from patronage to professional writing as being often abusive and hostile for women. Rotraud von Kulessa explores Luisa Bergalli's literary career as a playwright and journalist and examines the pitfalls for individuals, especially women, who gradually moved from patronage to a market economy that did not pay well for their writings and even usurped and abused their authorship, as was the case with Luisa's husband.

A different and more pleasant scenario for women who understood writing as a way of self-expression is depicted by Nieves Baranda, who uses the case studies of Luisa Sigea, Ana Caro, María de Zayas and individual nuns in seventeenth-century Spain to illustrate the rewards and promotion that these women obtained from the court in exchange for their plays, while they also wrote comedies that were successfully sold to publishers.

Economic imperatives thus influenced self-representation and the rhetorical strategies of women writers, as well as their publishing strategies. The entanglement of patronage and professionalism is obvious for example in Baranda's chapter, in which the literary careers of women, at a time when market economies were not fully developed, seemed to make the best of both worlds as they often combined the promotion and reputation that patronage gave them with a more tangible benefit from a vibrant public that consumed and paid for fiction works. Other strategies that emphasize the fragile balance between patronage and professionalism are publishing for the broader market as a precondition for patronage (as is shown in Geerdink's chapter) and using patronage as an alternative for market writing (Font Paz) or the other way around (Von Kulessa). Also in these cases, women were willing to have their writings 
read and even admired, since they often aimed to affect social change that put women at the centre.

To conclude, what the chapters in this volume show is that at a time in which a commercial market emerged while modes of patronage, in connection to this market, altered, women were actors of change and creativity by taking part in and representing themselves in relation to these developments. This volume hopes to encourage further comparative research to show how both the entanglement between patronage and professionalism and women's representation in connection to it took place within the differing contexts of various countries, both within and outside their borders.

\section{Bibliography}

Batchelor, Jennie. 2012. Women's Work: Labour, Gender, Authorship 1750-1830. Manchester/New York: Manchester University Press.

Bell, Maureen. 1996. 'Women in the English Book Trade 1557-1700', in Leipziger Jahrbuch zur Buchgeschichte 6:13-46.

Bouwmeester, Gerard, Nina Geerdink and Laurens Ham. 2015. 'Een veelstemmig verhaal. Auteurschap in de Geschiedenis van de Nederlandse literatuur' in Nederlandse letterkunde 20(3): 215-36.

Clery, E.J., Caroline Franklin and Peter Garside. 2002. Authorship, Commerce and the Public: Scenes of Writing, 1750-1850. London: Palgrave Macmillan.

Elk, Martine van. 2017. Early Modern Women's Writing. Domesticity, Privacy, and the Public Sphere in England and the Dutch Republic. Cham: Springer/Palgrave Macmillan.

Ellinghausen, Laurie. 2005. 'Literary Property and the Single Woman in Isabella Whitney's A Sweet Nosgay' in Studies in English Literature 1500-1900 45: 1-22.

Ellinghausen, Laurie. 2008. Labor and Writing in Early Modern England, 1567-1667. Aldershot/Burlington: Ashgate.

Ezell, Margaret J.M. 1999. Social Authorship and the Advent of Print. Baltimore: John Hopkins University Press.

Ezell, Margaret J.M. 1992. 'The Gentlemen's Journal and the Commercialization of Restoration Coterie Literary Practices' in Modern Philology 89(3): 323-40.

Gallagher, Catherine. 1994. Nobody's Story: The Vanishing Acts of Women Writers in the Marketplace 1670-1820. Oxford: Clarendon Press.

Geerdink, Nina. 2012. Dichters en Verdiensten. De sociale verankering van het dichterschap van Jan Vos (1610-1667). Hilversum: Verloren.

Griffin, Dustin. 2014. Authorship in the long Eighteenth Century. Newark: University of Delaware Press. 
Hammond, Brean. 1997. Professional Imaginative Writings in England, 1670-1740: 'Hackney for Bread' Oxford: Clarendon Press.

Hobby, Elaine. 1988. Virtue of Necessity: English Women's Writing 1649-88. London: Virago.

Hoftijzer, Paul. 2001. 'Women in the Early Modern Dutch Book Trade' in Van Dijk, Suzan et al (eds) Writing the history of women's writing. Amsterdam: KNAW: 211-22.

Hunt, Tamara. 1996. 'Women's Participation in the Eighteenth-Century English Publishing Trades' in Leipziger Jahrbuch zur Buchgeschichte 6: 47-66.

Kernan, Alvin. 1989. Samuel Johnson and the Impact of Print. Princeton: Princeton University Press.

King, Kathryn. 2002. 'Elizabeth Singer Rowe's Tactical Use of Print and Manuscript' in Justice, G.L. and N. Tinker (eds.) Women's Writing and the Circulation of Ideas: Manuscript Publication in England, 1550-1800. Cambridge: Cambridge University Press: $151-81$.

Lehmstedt, Mark. 1996. “'Ich bin nun vollends zur Kaufmannsfrau verdorben' ”. Zur Rolle der Frau in der Geschichte des Buchwesens am Beispiel von Friederike Helene Unger (1751-1813)' in Leipziger Jahrbuch zur Buchgeschichte 6: 81-154.

Loewenstein, Joseph. 2000. 'Wither and Professional Work' in Marotti, A.F., M.D. Bristol (eds) Print, Manuscript and Performance. Columbus: Ohio State University Press 2000 .

McDowell, Paula. 1998. The Women of Grub Street: Press, Politics, and Gender in the London Literary Marketplace, 1678-1730. Oxford: Clarendon Press.

Parker, Deborah. 1996. 'Women in the Book Trade in Italy, $1475^{-1620 '}$ in Renaissance Quarterly 49(3): 509-41.

Pender, Patricia and Rosalind Smith (eds). 2014. Material Cultures of Early Modern Women's Writing. Basingstoke: Palgrave MacMillan.

Pettegree, Andrew. 2010. The Book in the Renaissance. New Haven/London: Yale University Press.

Prescott, Sarah. 2003. Women, Authorship and Literary Culture, 1690-1740. Houndmills/ New York: Palgrave MacMillan.

Rose, M. 1993. Authors and Owners: the Invention of Copyright. Cambridge, MA: Harvard University Press.

Rose, M. 1988. 'The Author as Proprietor' in Representations 23: 51-85.

Schellenberg, Betty. 2005. The Professionalization of Women Writers in EighteenthCentury Britain. Cambridge: Cambridge University Press.

Sheridan, G. 2001. 'Women in the Book Trade in the 18th Century: An Untold Story' in Van Dijk, Suzan et al (eds) Writing the history of women's writing. Toward an international approach. Amsterdam: KNAW: 197-210

Sheridan, G. 1992. 'Women in the booktrade in eighteenth-century France' in British journal for Eighteenth-Century Studies 15: 52-69. 
Smith, Helen. 2015. Grossly Material Things. Women and Book Production in Early Modern England. Oxford: Oxford University Press.

Stanton, Judit. 1988. 'Statistical Profile of Women Writing in English from 166o to 180o' in Keener, Frederick and Susan Lorsch (eds) Eighteenth-Century Women and the Arts. New York: Greenwood Press: 247-54.

Turner, Cheryl. 1992. Living by the Pen. Women Writers in the Eighteenth Century. New York/London: Routledge.

Turnovsky, Geoffrey. 2010. The Literary Market. Authorship and Modernity in Old Regime France. Philadelphia: University of Pennsylvania Press.

Viala, Alain. 1985. Naissance de l'écrivain. Sociologie de la littérature à l'âge classique. Paris: Minuit.

Woodmansee, M. 1984. 'The Genius and the Copyright: Economic and Legal Conditions of the Emergence of the Author' in Eighteenth Century Studies 17(4): 425-28.

Wright, Gillian. 2013. Producing Women's Poetry. Text and Paratext, Manuscript and Print. Cambridge: Cambridge University Press. 